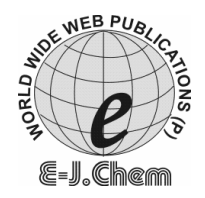

http://www.e-journals.net
ISSN: 0973-4945; CODEN ECJHAO

E-Journal of Chemistry 2010, 7(3), 785-788

\title{
Simple UV Spectrophotometric Determination of Duloxetine Hydrochloride in Bulk and in Pharmaceutical Formulations
}

\author{
MOHAMMAD YUNOOS*, D.GOWRI SANKAR ${ }^{\S}$, \\ B.PRAGATI KUMAR, SHAHUL HAMEED and AZMATH HUSSAIN \\ Nimra College of Pharmacy, Jupudi, Ibrahimpatnam, Vijayawada, India. \\ ${ }^{\S}$ University College of Pharmaceutical Sciences, \\ Andhra University, Visakhapatanam, Andhra Pradesh, India. \\ yunoos_pharmacyanalyst666@gmail.com
}

Received 14 October 2009; Accepted 5 December 2009

\begin{abstract}
A new, simple and sensitive spectrophotometric method in ultraviolet region has been developed for the determination of duloxetine hydrochloride in bulk and in pharmaceutical formulations. Duloxetine hydrochloride exhibits absorption maxima at $288 \mathrm{~nm}$ with apparent molar absorptivity of $0.97 \times 10^{4} \mathrm{~L} / \mathrm{mol} . \mathrm{cm}$ in $0.1 \mathrm{~N} \mathrm{HCL}$. Beer's law was found to be obeyed in the concentration range of $5-30 \mu \mathrm{g} / \mathrm{mL}$. The method is accurate, precise and economical. The proposed method has been applied successfully for the analysis of the drug in pure and in its capsule dosage forms. In this method, there is no interference from any common pharmaceutical additives and diluents. Results of the analysis were validated statistically and by recovery studies.
\end{abstract}

Keywords: UV Spectrophotometry, Duloxetine hydrochloride, Beer's law, Capsule.

\section{Introduction}

Duloxetine hydrochloride, chemically known as (+) - $(S)$ - $N$-methyl - $\gamma$ - (1- naphthyloxy) 2-thiophenepropylamine hydrochloride ${ }^{1}$ (Figure 1), is an antidepressant agent ${ }^{2}$. It is indicated for the treatment of major depressive disorder (MDD).It is a selective serotonin and nor-epinephrine reuptake inhibitor (SSNRI) for oral administration. A survey of literature showed few analytical methods has been reported for determination of duloxetine hydrochloride in human serum and biological fluids using tandem MS and LC-MS methods ${ }^{3}$ and HPLC $^{4-5}$ method for the estimation of duloxetine hydrochloride in pharmaceutical preparations. Determination of duloxetine hydrochloride by spectroflourimetric method ${ }^{6-7}$ has also been reported. To the best of our knowledge, there is no report on UV-Visible spectrophotometric method for its estimation. Therefore, an attempt was made to develop a 
simple, rapid, accurate and sensitive UV spectrophotometric method for the estimation of duloxetine hydrochloride in pure drug and in formulations i.e. capsules. UV analysis of duloxetine hydrochloride was performed in 0.1 N HCL. The spectrum was recorded from $200 \mathrm{~nm}$ to $400 \mathrm{~nm}$. The quantitative analysis was carried out at $288 \mathrm{~nm}$. The method was validated and applied for the determination of duloxetine hydrochloride in capsule dosage form.<smiles>CNCC[C@H](Oc1cccc2ccccc12)c1cccs1</smiles>

Figure 1. Chemical structure of duloxetine hydrochloride.

\section{Experimental}

ELICO SL-164 UV-Visible double beam spectrophotometer equipped with $10 \mathrm{~mm}$ matched quartz cells. A sartorius analytical balance was used.

\section{Chemicals}

Pure duloxetine hydrochloride (DXH) obtained from Orchid Chemicals and Pharmaceuticals Ltd., Chennai, was used as such without further purification. Different brands of capsules of DXH were supplied from local pharmacy.

\section{Recommended procedure and calibration curve}

DXH (100 mg) was accurately weighed and dissolved in $100 \mathrm{~mL} 0.1 \mathrm{~N} \mathrm{HCl}$ to form a stock solution $(1000 \mu \mathrm{g} / \mathrm{mL})$. The stock solution was further diluted suitably with $0.1 \mathrm{~N} \mathrm{HCl}$ to get a working standard solution of concentration $100 \mu \mathrm{g} / \mathrm{mL}$. This working standard solution was suitably diluted to give a concentration of $20 \mu \mathrm{g} / \mathrm{mL}$ and this was then scanned in UV range. This showed an absorption maximum at $288 \mathrm{~nm}$ (Figure 2). Aliquots $(0.5,1.0,1.5,2.0,2.5$ and 3.0$) \mathrm{mL}$ of working standard solution $(100 \mu \mathrm{g} / \mathrm{mL})$ corresponding to 5-30 $\mu \mathrm{g}$ were taken in a series of $10 \mathrm{~mL}$ volumetric flask and volume made up with $0.1 \mathrm{~N}$ $\mathrm{HCl}$. The absorbance measurements of these solutions were carried out against $0.1 \mathrm{~N} \mathrm{HCl}$ as blank at $288 \mathrm{~nm}$. A calibration curve of DXH was plotted (Figure 3). The concentration of the unknown was read from the calibration graph or computed from the regression equation.

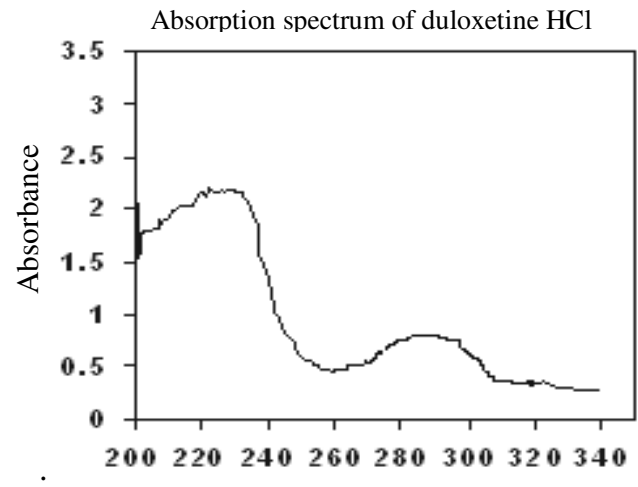

Wavelength, nm

Figure 2. Duloxetine hydrochloride scanned in UV range (in $0.1 \mathrm{~N} \mathrm{HCl}$ ). 


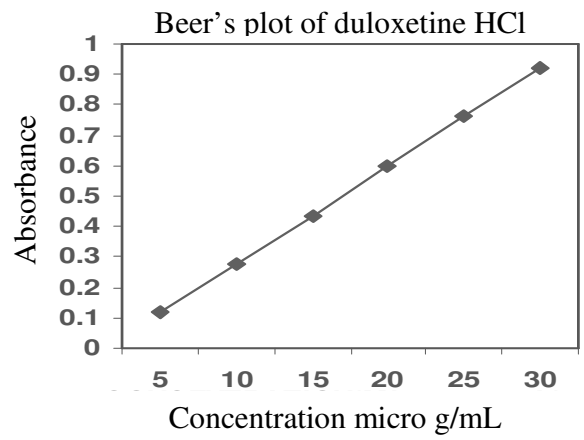

Figure 3. Standard plot of duloxetine hydrochloride.

\section{Procedure for capsules}

Two commercial formulation, dupact (M/s Wockhardt) and duxet (M/s Unichem) were purchased from local pharmacy. The contents of 20 capsules were mixed and accurately weighed amount of the contents equivalent to $100 \mathrm{mg}$ of DXH was transferred into a $100 \mathrm{~mL}$ volumetric flask. $70 \mathrm{~mL}$ of $0.1 \mathrm{~N} \mathrm{HCl}$ was added and the contents of the flask were shaken for $5 \mathrm{~min}$. The solution was then diluted to the mark with the $0.1 \mathrm{~N} \mathrm{HCl}$ to get a stock solution of $1000 \mu \mathrm{g} / \mathrm{mL}$ The content of the flask was filtered through Whatman filter paper No. 1 and $10 \mathrm{~mL}$ of the filtrate was diluted to $100 \mathrm{~mL}$ with $0.1 \mathrm{~N} \mathrm{HCl}$ in a $100 \mathrm{~mL}$ volumetric flask to give a concentration of $100 \mu \mathrm{g} / \mathrm{mL}$ Suitable volume of this solution was taken in $10 \mathrm{~mL}$ volumetric flask and volume was made up with $0.1 \mathrm{~N} \mathrm{HCl}$. Absorbances were read and concentrations of DXH determined using the calibration curve. Calculations were then made with the dilution factor to find out the concentration of the drug in capsules. The experiments were repeated six times to check its reproducibility.

\section{Results and Discussion}

The proposed method for determination of duloxetine hydrochloride showed molar absorptivity of $0.97 \times 10^{4} \mathrm{~L} / \mathrm{mol} . \mathrm{cm}$. Linear regression of absorbance on concentration gave the equation $y=0.0322 x+0.0042$ with a correlation coefficient $(r)$ of 0.9998 . The optical characteristics such as Beer's law limit, Sandell's sensitivity, \% Range of error (0.05 and 0.01 confidence limits) were calculated and are summarized in Table 1. Statistical analysis of commercial formulations has been shown in Table 2 .

Table 1. Optical characteristics of duloxetine hydrochloride.

\begin{tabular}{lc}
\hline \multicolumn{1}{c}{ Parameters } & Results \\
\hline$\lambda_{\max }, \mathrm{nm}$ & 288 \\
Beer's law limit, $\mu \mathrm{g} / \mathrm{mL}$ & $5-30$ \\
Molar absorptivity, $\mathrm{L}$ mole ${ }^{-1} \mathrm{~cm}^{-1}$ & $0.97 \times 10^{4}$ \\
Sandell's sensitivity & 0.033 \\
$\left(\mu \mathrm{g} \mathrm{cm}^{-2} / 0.001\right.$ absorbance unit) & \\
Regression equation $(\mathrm{Y}=\mathrm{a}+\mathrm{bC})$ & \\
Slope (b) & 0.0322 \\
Intercept (a) & 0.0042 \\
Correlation coefficient (r) & 0.9998 \\
\% Range of error (Confidence limits) & \\
0.05 level & 0.1923 \\
0.01 level & 0.2845 \\
\hline \multicolumn{2}{c}{ *Average of six determinations. }
\end{tabular}


Table 2. Statistical analysis of duloxetine hydrochloride capsules.

\begin{tabular}{cccc}
\hline Brand & $\begin{array}{c}\text { Labeled amount } \\
\mathrm{mg} / \text { capsule }\end{array}$ & $\begin{array}{c}\text { Amount found } \\
\mathrm{mg} / \mathrm{capsule}\end{array}$ & $\begin{array}{c}\text { \% Label claim } \\
\pm \mathrm{SD}^{*}\end{array}$ \\
\hline $\begin{array}{c}\text { Dupact } \\
20 \mathrm{mg}\end{array}$ & 20 & 19.9965 & $99.98 \pm 0.14$ \\
Duxet & & 19.9997 & $99.99 \pm 0.23$ \\
$20 \mathrm{mg}$ & 20 & \multicolumn{4}{c}{ *Average of six determinations. }
\end{tabular}

Table 3. Recovery studies of duloxetine hydrochloride capsules.

\begin{tabular}{cccc}
\hline Brand & $\begin{array}{c}\text { Amount added, } \\
\mathrm{mg}\end{array}$ & $\begin{array}{c}\text { Amount found, } \\
\mathrm{mg}\end{array}$ & $\begin{array}{c}\text { \%Recovery } \pm \\
\text { SD* }\end{array}$ \\
$\begin{array}{c}\text { Dupact, } \\
20 \mathrm{mg}\end{array}$ & 5 & 29.9972 & $99.99 \pm 0.22$ \\
$\begin{array}{c}\text { Duxet, } \\
20 \mathrm{mg}\end{array}$ & 5 & 29.9925 & $99.97 \pm 0.15$ \\
\hline \multicolumn{4}{c}{ *Average of six determinations. }
\end{tabular}

\section{Conclusion}

In this study a simple, rapid, sensitive, accurate and precise UV spectrophotometric method for the determination of duloxetine hydrochloride in bulk and pharmaceutical formulation has been developed and validated. It was found that the common excipients present in the formulation did not interfere with the proposed method and can be used for the routine quality control analysis of duloxetine hydrochloride in bulk as well as in marketed capsules.

\section{References}

1. Sweetman S C, In: Martindale, The complete drug reference, $34^{\text {th }}$ Ed. London: Pharmaceutical Press; 2005, 291

2. Brunton L L, Parker K S and Lazo J S, In: Goodman and Gillman's, the Pharmacological Basis of Therapeutics, $11^{\text {th }}$ Ed. London: McGraw Hill Publishing; 2005, 436-50.

3. Johnson J T, Oldham S W and Lantz R J, J Liq Chromatogr Rel Technol., 1996, 19, 1631-41.

4. Soni P, Mariappan T T and Banerjee U C, Talanta, 2005, 67, 975-978.

5 Laura Mercolini, Roberto Mandrioli and Roberto Cazzolla, J Chromatogr. B, 2007, 856, 81-87.

6. Xiangping Liu, Yingxiang Du and Xiulan Wu, Spectrochimica Acta Part A: Mol Biomol Spectrosc., 2008, 71, 915-920.

7. Prabhu S L, Shahnawaz S, Dinesh Kumar C and Shirwaikar A, Indian J Pharm Sci., 2008, 70, 502-503.

8. Beckett H A and Stenlake B J, Practical Pharmaceutical Chemistry; $4^{\text {th }}$ Ed.,CBS Publishers, New Delhi, 2001, 274. 


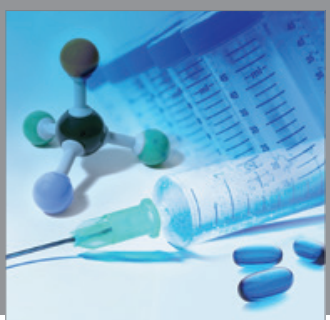

International Journal of

Medicinal Chemistry

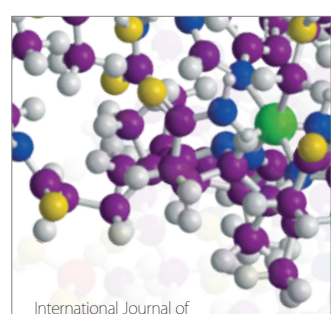

Carbohydrate Chemistry

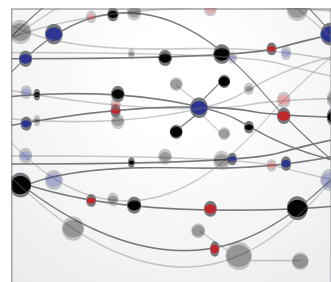

The Scientific World Journal
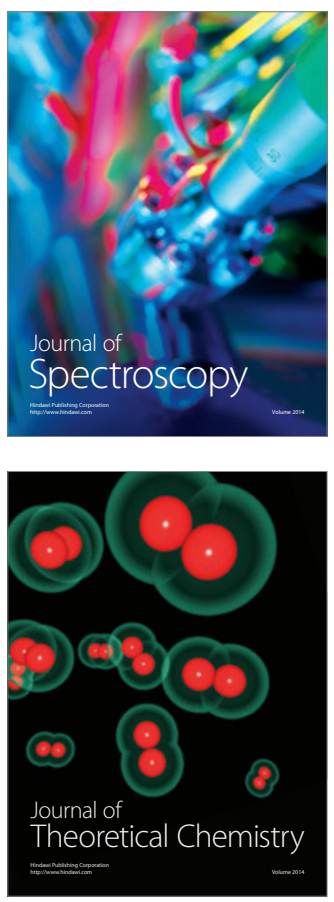
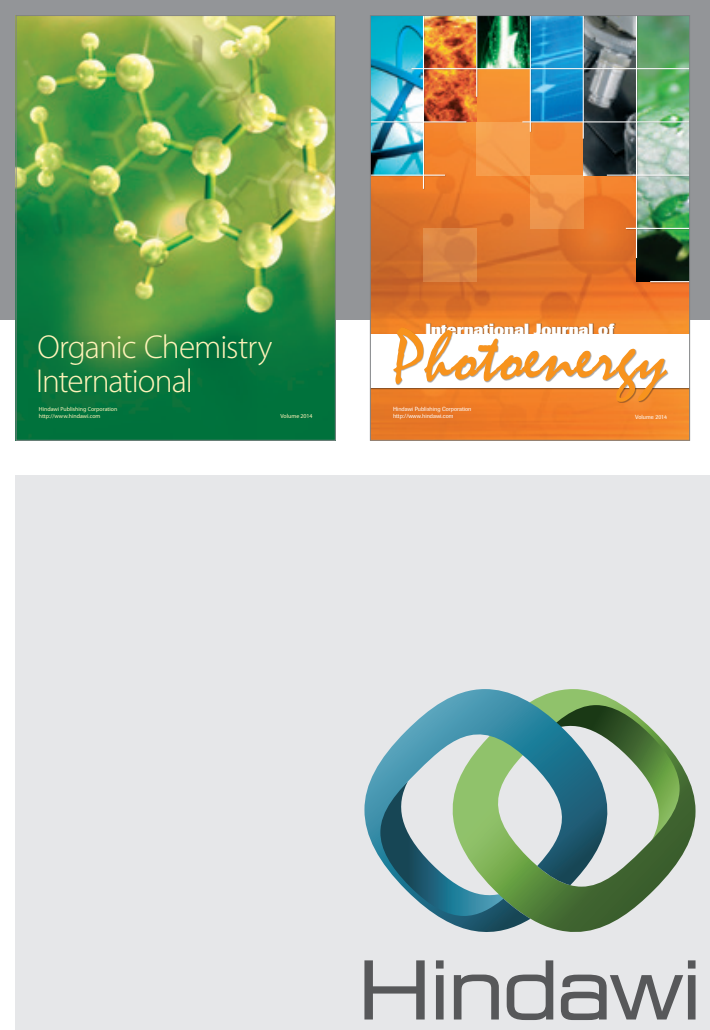

Submit your manuscripts at

http://www.hindawi.com
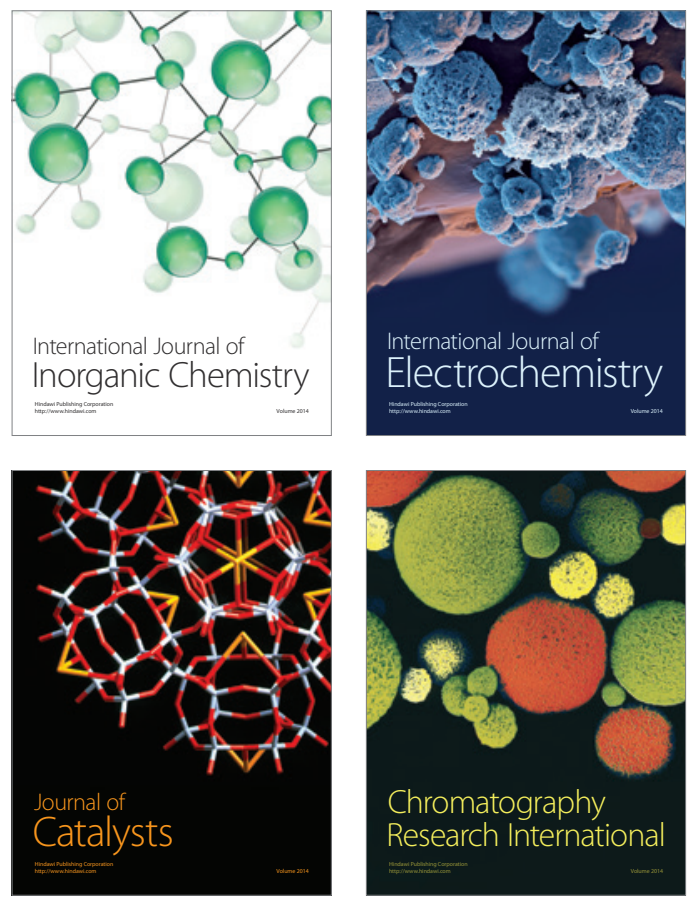
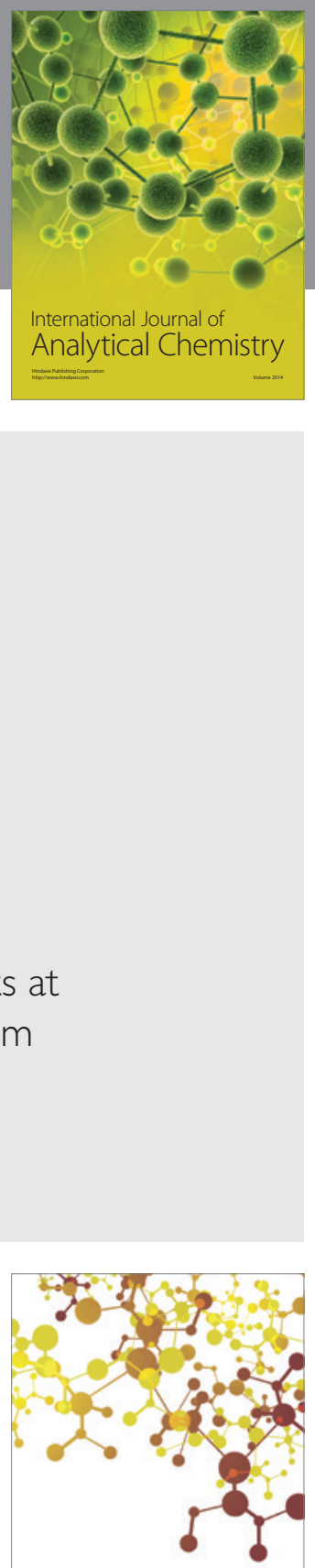

Journal of

Applied Chemistry
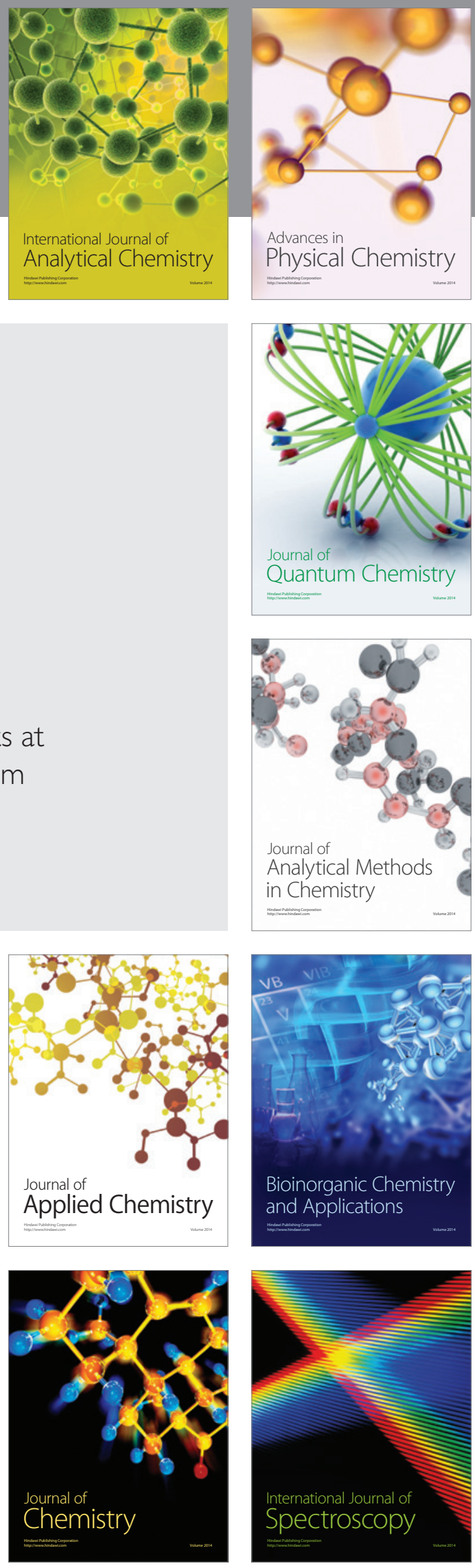